\title{
THE ROLE OF NATIONAL COUNCIL FOR HIGHER EDUCATION IN GOVERNMENT OF UNIVERSITIES IN UGANDA
}

\author{
A.B.K. Kasozi \\ Executive Director \\ National Council for Higher Education
}

\section{Summary}

In this paper I will discuss the mandate of the National Council for Higher Education in the government of higher education and the measures Council has so far part in place to carry out its mandate. I will also deal with challenges the Council faces in carrying out its mandate.

\section{The mandate of Council}

The National Council for Higher Education derives its mandate from the Universities and Other tertiary Institutions Act. 2001 and the amendments of the Act in 2003 and 2006. As the name of the Act suggests, the mandate of Council is not confined to Universities but extends to what is called "other tertiary institutions". These are post "A" Level institutions that award diplomas and certificates. Another category of institutions was added in the 2006 amendment of the Act. This is the category of Other Degree Awarding Institutions. Typical of these and the only one of the type as of now is the Uganda Management Institute (UMI). Such an institution can award degrees without being a university.

Before we discuss the role of National Council in the governance of universities, let me emphasize one cardinal principle enshrined in the Act, which many people tend to lose sight of, unfortunately. I say unfortunate advisedly because even those who ought to know make the mistake of thinking that the Council is there to run or micromanage universities.

The objectives of the Act are explicit on this matter. The Act sets out to:-

The caveat is that the above must be done "while at the same time respecting the autonomy and academic freedom of institutions"

In section 5 of the Act the following functions are assigned to National Council:

a) To implement the objects of the Act.

b) To promote and develop the processing and dissemination of information on higher education for the benefit of the people.

c) To advise the Minister on the establishment and accreditation of public and private institutions of Higher Education

d) To receive, consider and process applications for the establishment and accreditation of public and private institutions of Higher Education.

e) To register all institutions of Higher Education establishment under this Act.

f) To receive and investigate complaints relating to institutions of Higher Educa- 
tion and take appropriate action.;

g) To monitor, evaluate and regulate institutions of Higher Education;

h) In co-operation with the relevant Government departments, private sector, or the different institutions of Higher Education, to evaluate the overall national manpower requirement and recommend solutions to the requirements;

i) To ensure minimum standards for courses of study and the equating of degrees, diplomas and certificates awarded by the different public and private institutions of Higher Education;

j) To set and co-ordinate national standards for admission of students to the different institutions of higher education;

k) To determine the equivalent of all types of academic and professional qualifications of degree, diplomas and certificates obtained elsewhere with those awarded by Uganda institutions of Higher Education for recognition in Uganda.

1) To certify that an institution of Higher Education has adequate accessible physical structures and staff for the courses to be offered by it.;

m) To promote national interests in courses of study and professional qualifications among the different types of institutions of Higher Education;

n) To ensure that adequate facilities and opportunities for carrier guidance and counseling are provided by the institutions;

o) To collect, examine and publish information relating to the different institutions of Higher Education.

p) To generally advise the government on policy and other matters relating to institutions of Higher Education;

q) To person any other function incidental to objects of this Act or relating to higher education in Uganda or that may be conferred upon it by the Minister or any other law;

It is sometimes common for people to think of these 17 functions negate the institutional autonomy and academic freedom which is clearly stated in the objects of the Act. One public university where academic staff we having problems with the university administration went as far as suggesting to a Sessional Committee of Parliament tat the university administrators should be dismissed and national Council should take over the administration of the university. That was a gross misunderstanding of the role of Council.

\section{The 17 functions of Council can be summarized under:}

a) Establishment of institutions of higher education.

b) Ensuring that institutions have and maintain high standards.

c) The equating of qualifications

d) Creating and making available information on higher education.

e) Advising government on policy issues relating to higher education.

f) Doing other things relating to the Act or as may be assigned by the Minister from time to time.

\section{Establishment of institutions of higher education}

You are concerned with universities, so let us confine the discussion to universities. The role of Council in the establishment of public universities is spelt out in Section 22 of the Act. 
1) "The Minister may by statutory instrument on the recommendation of the National Council and by resolution of Parliament, establish a Public University".

2) "The National Council shall within thirty days of the publication of the statutory instrument in the Gazette register the public university established under subsection (1)".

In this matter the role of the National Council is twofold: to make a recommendation to the Minister responsible for education that a public university should be established and when the Minister has secured a resolution of Parliament to that effect and has issued a Statutory Instrument creating the university, Council to register the university. The effect of this registration is that the academic awards by the university are recognized in Uganda. This is the only rote through which a public university can be created and through which its academic awards can be recognized in Uganda and ipso facto outside Uganda

The role of Council in the establishment of a private university is more elaborate and stakes several stages. To begin with, no private university can be established in Uganda without a valid license from the National Council. Section 118 of the Act makes it an offence to do otherwise. The first stage of the licencing process is the Letter of Interim Authority. The holder of this letter of Interim Authority is allowed to mobilize resource, develop the university project further, develop infrastructure, recruit some administrative staff but cannot admit students. This authority is valid up to three years. The second stage is the provisional licence. The holder of this licence is allowed to recruit students and to establish a university. The licence is valid for at least three years after which the holder can apply for a charter and full accreditation. The applicant must meet rigorous standards set by Council before Council can recommend to the President through the Minister to grant a Charter.

\section{Standards}

One of the crucial roles of Council is to set standards and to ensure that universities meet and maintain these standards. Sections, 5, 6, 119 and 123 of the Act empower Council to do so. The Council is required to take the following measures:

a) To accredit all academic and professional programmes before they can be taught.

b) To ensure that there are minimum standards for courses for study. To this end Council has established these standards in Mathematics and Economics. We are finalizing standards for Social Sciences, Basic Sciences, Statistics and Human Medicines. Please note we set minimum standards below which you should not tech. We leave you to aim at reaching the sky. Let me also say that in working out these minimum standards we use academicians from universities.

c) To establish minimum entry requirements for students entering universities. This is a measure to ensure that those who enter universities are at a standard to benefit from university education. These standards will be published soon in the revised Statutory Instruments No. 84 of 2005.

d) To establish standards for people who teach in universities. Under the law you cannot teach in a University unless you meet the academic standards set 
by Council. These standards have already been approved by Council and the Minister and are with the Solicitor General for gazeting.

e) Gazeting of standards for institutional capacity indicators, libraries, curriculum and physical facilities. These standards have been published in Statutory Instruments No. 80 and No. 85 of 2005.

\section{Equating of qualifications}

Under this role Council is required to do three things:

a) To equate qualifications awarded by different institutions in Uganda.

b) To equate foreign qualifications with those obtained in Uganda

c) To determine whether or not politicians who want head Local Council V, stand for Parliament of office of the President have the required academic qualifications.

Does this have anything to do with the governance of universities? Surprisingly; Yes. It has to do with whether people you admit for various courses have met Council's minimum standards for entry into various courses and whether you mature entry scheme can be equated to the equivalent of " $A$ " level certificate of education. We have to answer these issues in courts of law. In turn where our standards of entry and duration of courses have not been met we ask universities to answer.

\section{Creating and making information on higher education available}

Higher education institutions and universities in particular, are creators, organizers and disseminators of information. As a higher education regulatory Council we are expected to create, generate and disseminate information. We are expected to do more than this. We are expected to set standards for university in this area. We have already talked of standards for university libraries which we published in Statutory Instrument No. 85 of 2005. Other standards regarding aspects of ICT and publications by academicians are found in Statutory Instruments No. 80 of 2005.

\section{On its part Council has put out the following publications:}

a) Uganda Higher Education Review: a Journal of the National Council for Higher Education.

b) The State of Higher education, 2004, 2005, and 2006 will come out soon.

c) Minimum Requirements for Courses of Study: Mathematics and Economics.

d) Quality Assurance Framework for Uganda Universities.

e) Statutory Instruments No. 80, 84 and 85 and 2005.

f) Graduate Tracer and Employers Expectations studies.

\section{Advising government on issues relating to Higher Education}

From time to time various agencies and department of government require information and advice from Councils on arrange of issues relating to higher education. This information has ranged from fees paid in universities outside Uganda, qualifications from certain institutions abroad to information on General agreement on Trade in Goods and Services. Under giving advice to government, we have been asked to do fire brigade work at universities which are on strike. We have been asked to go in and put out fire 
and advise government on what needs to be done next.

\section{Capacity building}

Right from the time the National Council was established, we realized the importance of equipping universities with information managing universities.

This has taken various forms:-

a) As already said above, we have put out a number of publications. Some of these have been as a result of research in higher education institutions.

b) We have held a number of training workshops for university managers in Jinja, Entebbe, and Kampala. We have an on-going programme of training universities to carry out self-evaluation and academic audit. We have participated in planning and training workshops of various universities. We were with you in Mukono at your Planning retreat from $9^{\text {th }}-13^{\text {th }}$ February 2007 and we are with you at this induction workshop. We hope out involvement with you will help in building our and your capacity. It works both ways.

\section{Challenges}

In our role of governance of universities in Uganda we meet a number of challenges. I will summarize them thus:-

a) Misconception of our role. There are those who mistake our regulatory role to be that of policing. This tends to be the case with universities which have failed to meet our standards.

b) For us to perform our role well, we need numbers and skills. Our numbers as a secretariat of Council are far from adequate and a young institution operating in a new area of university regulation outside a Ministry of Education, we have knowledge and experience gaps. At the level of universities, management skills are sometimes equally inadequate.

c) Inadequate funding of universities makes our work as a regulator difficult, especially when it comes to enforcing standards and good governance in universities.

d) The law under which we operate has some inadequacies, in spite of the 2006 amendment. 